\title{
Erratum to: Eugenics, the Genome, and Human Rights
}

\section{Daniel J. Kevles}

Published online: 11 June 2010

(C) Springer Science+Business Media B.V. 2010

Erratum to: Medicine Studies (2009) 1:85-93 DOI 10.1007/s12376-009-0010-z

In the original article the copyright line reads: Springer Science+Business Media B.V.
This is not correct.

The copyright line should have read:

Daniel J. Kevles (the author)

Everything else in the paper remains correct.

The online version of the original article can be found under doi:10.1007/s12376-009-0010-z.

D. J. Kevles $(\square)$

Department of History, Yale University, P.O. Box 208324,

New Haven, CT 06520-8324, USA

e-mail: daniel.kevles@yale.edu 